$2020,9(2)$, pp. 284-303, DOI: 10.18036/estubtdc. 656857

\title{
REVIEW
}

\section{MICROPLASTICS IN OUR PLANET: SOURCE, DISTRIBUTION, EFFECTS AND BIODEGRADATION}

\author{
NAHDHOIT AHAMADA RACHID ${ }^{1}$ (i) , NIHAL DOĞRUÖZ-GÜNGÖR ${ }^{2, *(i)}$ \\ ${ }^{1}$ Istanbul University, Institute of Graduate Studies in Sciences, 34134 Vezneciler, Istanbul, Turkey \\ 2 Istanbul University, Faculty of Science, Department of Biology, 34134 Vezneciler, Istanbul, Turkey
}

\begin{abstract}
In the last decade, the environmental problems of microplastics have been occupied a large place in world scientific researches. The unbreakable property of these particles causes their rapid accumulation in the environment. Their micro and millimetric sizes let them be distributed over the world in a way almost uncontrollable. Works are still multiplying in the identification of the source and nature, in the fate and effects of the microplastics on the different ecosystems. The accumulation of this debris in our ecosystem is a serious problem in the way of their distribution and migration: from the aquatic to the terrestrial ecosystem, all food web class will be affected. Different solutions for escaping their over distribution in the world have been studied. However, the biodegradation of these tiny particles seems the perfect solution for their disappearance from our environments. Studies seem slowly progressed because of different types of microplastics and the unknown mechanism of most of the microorganisms on the surface of microplastics. This review is a synthesis of works done in microplastics by offering a good comprehension of microplastics source, effects, and biodegradation in both aquatic and terrestrial ecosystems. Researchers will have to expand their working fields by approaching to the extreme ecosystems such as caves in the hope of finding microorganisms capable of producing enzymes that could serve in complete degradation of this debris.
\end{abstract}

Keywords: Microplastics, Biodegradation, Microorganisms

\section{INTRODUCTION}

Basically, plastics are made up of carbon, hydrogen, silicon, oxygen, chloride, and nitrogen [1]. From the discovering of the first synthetic polymer "Bakelite" in 1907, based on Phenol-formaldehyde, the production of these synthetic or semi-synthetic polymers still increasing with different formulations depending on different uses [2]. Plastic materials are of wide importance due to their lightweight, low thermal, low electric conductivity, durability properties as well as their low-cost manufacturing which allow them to be used in our daily needs and in more advanced sectors like in technology and medicine. The global plastics production has been estimated to 348 million tons in 2017 and 360 million tons in 2018 [3].

Microplastic is the term used by Thomson et al. (2004) to identify the microscopic pieces of plastics accumulated in sediment and water column of European waters [4-5]. Even-though authors in different studies have used different length limits to define their microplastic specimens, microplastic can be defined as "the plastic particles $<5 \mathrm{~mm}$ in diameter which include particles in the nano-size range $(1 \mathrm{~nm})$ " according to the Joint Group of Experts on the Scientific Aspects of Marine Environmental Protection (GESAMP) [6].

Microplastics in our days, constitute a great public debate due to their ubiquitous and persistence in the environment. The Association of Plastics Manufacturers (PlasticsEurope) gives an overview of the plastic post-consuming wastes and shows that even since 2006 plastic wastes generation sent to recycling still doubling every year but in $2018,25 \%$ of these wastes were still discharging on the landfill [3]. In this report, the authors include the hole of the plastics (large items and microplastics) [3]. The distribution of microplastics and their occurrence everywhere even on the high mountain points and deeps of ocean [7, 8-10] create an important subject for researchers to understand and get solutions for

*Corresponding Author: ndogruoz@istanbul.edu.tr

Received: 09.12.2019 Published: 30.07.2020 
these new major environmental pollutants. The impact of microplastics in the environment affects the whole living organisms. Even though, sometimes it can be indirectly. Many studies in this field are rapidly multiplying. Among them, researchers have observed the biofilm formation between some microorganisms and different microplastics. These observations can be ones of the most effective solutions of the microplastic contamination.

In this review, available information about microplastics source, distribution, effects on the environment and biodegradation as a solution to their accumulation on the environment, are synthesized. A background of microplastics classifications and properties has been introduced firstly. Source of environmental microplastics and their distribution over the ecosystems (marine and continental) have been discussed through studies which have done in these different environments. For further understanding the microplastics contamination and their potential risks in the environment, a synthesis of the studies carried out at the aquatic level as well as at the continental level have been elaborated. However, the recycling of the plastics post-consuming wastes generation is not enough for ending with the microplastics contamination. In this review, the biodegradation of microplastics by using microorganisms have been more explained with a concrete example of microorganisms found to be more effective on these particles during many nowadays studies. Some suggestions are also provided for further research work.

\section{CLASSIFICATION OF MICROPLASTICS}

\subsection{Classification of Microplastics According to the Origin of Microplastics Production}

According to their origin, Cole et al. (2011) have classified microplastics into primary and secondary microplastics [11].

\section{1.a. The Primary microplastics}

The primary microplastics are those which are produced within microscopic dimensions [11]. They are produced for industrial importance as well as domestic applications. Among them we can found nurdles (used as raw materials in plastic production industries), those present in cosmetic and self-care products like toothpaste, shower gels, facial cleanser, bubble bath lotions, hair coloring, insect repellents, etc [12, 13-14]. Microplastics have been identified in approximately $6 \%$ of the liquid skin-cleaning products sold in the European Union, Switzerland and Norway [15]. Hernandez et al. (2017) have confirmed the (unexpected) presence of nanoparticles in size from $24 \pm 6$ to $52 \pm 14 \mathrm{~nm}$ of polyethylene in three different facial scrub products [16].

\section{1.b. The Secondary microplastics}

The secondary microplastics are obtained from the fragmentation of macroplastics into smaller particles [11-17]. This fragmentation can be with mechanical intervention or after exposition to weather conditions. Plastic bags, bottles, medical materials and others can be recycled after to be used. However, during the recycling process, some smaller particles can scape to the environment. In addition, depending to the biotic and abiotic factors present in plastics disposing place as well as the type of plastic carbon backbone and additive materials, the plastics items can be fragmented into different sizes and shapes. For example, the ultraviolet radiation from the sunlight can cause oxidation of the polymer matrix which causes cleavage of the bonds $[6,10,18-20]$. The atmospheric oxygen, wave action, abrasion, turbulence and other mechanical forces can combine and act together to make the larger plastic items more vulnerable to be fragmented into microplastics [21, 22].

\subsection{Classification of Microplastics According to the Thermal Properties of Microplastics}

The physicochemical properties of plastics are depending to the nature of the raw material used in the production and the additive materials which define the lightness, durability, degradability, thermal 
stability and electrical conductivity of the plastic [1]. As it is mentioned above, the microplastics could be the raw material of large plastics or results of the fragmentation of these large items. By this fact, the properties of microplastics do not differ from those of plastic materials. According to the thermostatic action of plastics, plastics can be divided into two families: "Thermoplastics" and "Thermosets" [3].

\section{2.a. The Thermoplastics}

The manufacture of thermoplastics involves breaking the double bond in the original olefin by additional polymerization to form new carbon-carbon bonds [23]. In this part, we can site the polyolefins: polyethylene and polypropylene, polystyrene, polyvinyl chloride, polyethylene terephthalate, polyamides and polymethyl methacrylate [3]. They are characterized by repeated softness and hardness by heating and cooling (their shape can be changed after been heated). In addition, they are known as common plastics with a molecular weight ranged from 20,000 to 500,000 AMU (atomic masse unit) [24]. The structure of microplastics is of a backbone exclusively built of carbon atoms that makes them resistant to degradation or hydrolytic cleavage of chemical bonds [23].

\section{2.b. The Thermosets}

Contrary to the thermoplastics, thermoset plastics are irreversible from the solid to the liquid phase after being melted by heating. This type of plastics is made by condensation between two functional groups: carboxylic acid and an alcohol or an amine group. The main chain of the thermoset plastics is made by different atoms with a highly cross-linked structure. This cross-bond prevent the plastic material to flow after reheating, further heating can induce only a chemical breakdown without melting [25-26]. Some examples of this plastic category are unsaturated polyesters, phenolic resins, polyurethane, epoxy resins, vinyl esters, silicone and melamine resin [3].

\subsection{Classification of plastics according to the Society of the Plastics Industry (SPI)}

In 1988, in order to help consumers and plastic waste managers to identify the different types of plastics, the SPI had established a plastic classification. Combination of number and letters are usually found on the surface of the plastic item. These symbols indicate the type of plastic used, so its classification and properties. Some plastics are manufacturing with high or light density / molecular weight like Polyethylene (Low-Density Polyethylene and High-Density Polyethylene). In this part, we choose the five more used plastic materials and gave an overview of their properties.

- Polyethylene Terephthalate (PET/PETE)

PET which is usually noted on many common objects like water bottles, clothing and carpet fiber represents an odor and flavor absorber material. Items made from PET material are commonly recycled. The number " 1 " also represents this plastic type. It has a melting point of $250-260^{\circ} \mathrm{C}$ (thermoplastic). As a polyethylene, the polyethylene terephthalate has a crystalline morphology.

- High-Density Polyethylene (HDPE)

Polyethylene is one of the polyolefins. The High-Density one is known for its safety face to the transmission of any chemicals into foods or drinks. They are classified in the commonly recycled materials. Reusing items made from HDPE for food or drink conservation is never safe if this item didn't the original container. Items made from HDPE include bottles and containers for milk, shampoo, soap and detergents. It is highly used for packaging materials. It is used also in the manufacturing of building and construction materials as well as many other useful materials. The SPI had chosen the number "2" as the representation number of HDPE. It is a crystalline thermoplastic material and has a melting point of $130^{\circ} \mathrm{C}$.

- Polyvinyl Chloride/Vinyl Chloride (PVC/V)

PVC is an amorphous thermoplastic with a density value of $1.16-1.58 \mathrm{~g} \cdot \mathrm{cm}^{-3}$ and a melting point of $800^{\circ} \mathrm{C}$. Due to its additive materials like cupper, di (2-ethylhexyl) adipat, dioxins, ethylene dichloride 
and vinyl chloride, this material is classified in the "sometimes recycled" category. Items made from PVC/V should be disposable material: cannot be reused. These items include the credit cards, sports materials, some foods coatings, plumbing pipes and all kinds of tiles. Polyvinyl Chloride is attributed to the number " 3 " according to the plastic recycling property.

- Low-density Polyethylene (LDPE)

LDPE has a crystalline morphology. It is a thermoplastic material. Usually items made from this material can be reused due to its healthy, durability and flexible properties. However, it is sometimes recyclable with the number " 4 " as the distinction number according to the plastic recycling property. The melting point and surface density of LDPE is of $110^{\circ} \mathrm{C}$ and $0.910-0.940 \mathrm{~g} . \mathrm{cm}^{3}$ respectively. It is preferable than other plastic materials because of its good moisture barrier properties. It is for this reason that many packaging materials are made from it. Films as cling wrap, some laboratory materials like flexible bottles, agricultural materials as irrigation pipes and fertilizer bags are some examples of materials made from LDPE.

- Polypropylene (PP)

Polypropylene is commonly used in the fabrication of most bottle tops, ketchup, syrup, yogurt, and some margarine containers. It is a crystalline thermoplastic and excellent chemical resistant material. It is classified in the "occasionally recyclable" class of plastics. PP is a strong polymer with a melting point of $160^{\circ} \mathrm{C}$. Even it is hard, high temperature resistant and strong, this plastic material appears flexible with a waxy surface. The SPI had accorded the number " 5 " as the distinction number of the polypropylene.

\section{DISTRIBUTION OF MICROPLASTICS IN OUR PLANET}

In the last decades, the world lives an explosion of plastics utilization. These synthetic valuable resources that offering sustainable solutions in countless sectors are unfortunately imperishable. With their properties of light, micro-size particles, the microplastics have the privilege to be transported everywhere by different weather phenomena.

\subsection{Microplastics in Marine Environment}

From the 2000s, scientists investigate the microplastics occurrence in marine environment and studies still increasing every day for obtaining data of their distribution and effects [10]. Alomar et al. (2016) in a study conducted in the Mediterranean Sea especially in coastal shallow sediment, show the presence of microplastics in sediment from Marine Protected Areas in high concentration [28]. Additionally, researchers proved the presence of microplastics even on frozen areas, within the Arctic and Antarctic $[8,9,27]$.

Microplastics in the marine environment are from two main origins: directly by the primary microplastics and fragmentation of large items. $80 \%$ of microplastics founding in the ocean are estimated to come from the terrestrial activities [29]. In 2004, Thomson and his co-researchers have investigated some beaches, estuarine and subtidal sediments around Plymouth in the UK. They found the presence of microscopic synthetic polymers which are identified as acrylic, alkyd, poly (ethylene/ propylene), polyamide (nylon), polyester, polyethylene, poly-methylacrylate, polypropylene and polyvinyl-alcohol. Authors suggest that some of them come from the fragmentation of large plastic items like clothing, packaging and rope [5]. Domestic effluents contribute to the marine micro-litter. Microbeads founding in these marine litter are mainly coming from the primary microplastics present in cosmetic products, clothing washing waters, [11-30] etc. Microplastics with characteristics similar to those of commonly produced from clothes washing have been detected from marine sediment samples collected from near the station sewage treatment plant outfall in Antarctica [31]. In addition, no particles detected at Rose Garden c. which is located at $7 \mathrm{~km}$ from this station; that gives the idea that the more the sites are closer to the land-based activities, the more these sites are polluted.

The Source of microplastics in the ocean can also be the activities realized in the ocean. It is the source of about $20 \%$ of these marine present plastic debris with fishing activities as a major human contribution 
[21]. In 2010, about 640,000 tons of discarded fishing gears are estimated to be added into the ocean every day which is estimated to approximately $10 \%$ of the total marine debris [21-32].

The distribution of microplastics along the water surface, the beach or bottom sediments, is depending to the size, the gravity, the density of microplastic types and some mechanisms like cyclones and flooding. Light and soft items will be floating above or on the sea water surface or column, while the largest and heavy ones will migrate to the deep-sea bottom [21-33]. Presence of plastic particles in some sub-surface samples recorded from the southern California during winter off gives the idea that particles > $0.5 \mathrm{~mm}$ in size are concentrated near the ocean surface due to their buoyancy in seawater. In this same study, authors suggest that the winter conditions of higher turbulence in the water column are likely conductive to mixing of plastics into the water column from the surface or the sediments and explain the restriction of sub-surface particles to the winter samples [33]. The time spent by the microplastic in these environments has also an important role in the distribution of these micropolymers. A Study in the microbial biofilm formation on marine plastic debris shows a physicochemical property change of this debris without observation or confirmation of the participation of these microorganisms in the biodegradation of these polymers [34].

\subsection{Microplastics in Freshwater}

The majority of microplastics researchers have been focused on the marine environment. Recently some studies have been oriented to other ecosystems like the freshwaters. However, information and data about the distribution and occurrence of microplastics in freshwater ecosystems are limited in front of those of the marine environment. Lambert and Wagner, (2018) have reported that only 4\% of microplastic studies are focused on the freshwater ecosystem [35].

Concentrations of microplastics in aquatic environments like lakes and rivers are observed to be highly heterogenous comparable to those on the marine environment. It has resulted from more than one factor: position of the freshwater source (weather conditions, physicochemical properties of this placement), human activities around this source, etc [36]. Along the middle and lower reach of the Yangtze River (about 15 sites), study done in 2019 shows that an average of $4.92 \times 10^{5}$ items $/ \mathrm{km}^{2}$ of microplastics is abundant [37]. The abundance of microplastics may be important in big cities than in rural regions. Peng et al. (2018) have conducted a case study in the risk assessment in megacities by studying microplastics in some freshwater river sediments in Shanghai. Here, authors found that the concentration of microplastics in rivers near the most populated areas was one or two greater than in the tidal flat in rural regions of this city. About 802 items/Kg of the dry weight of microplastics, in which polypropylene was the most present, were found in the six investigated rivers [38].

Sources of these particles distributed in freshwater environment are not different from that of the marine environment: land-based activities like household waste released in rivers, lakes, etc. Other activities like after or during wastewater treatment should be one of major sources of the freshwater ecosystem pollution. In their study in Sarajevo, researchers found that even though most polyethylene microbeads are stopped by the activated sludge, approximately a value of $1 \mathrm{~kg}$ is released into the Ljublanjca River [39]. Even $95 \%$ of microplastics could be removed by the wastewater treatment plants (WWTPs) and $90 \%$ of particle of size $10 \mu \mathrm{m}$ are removed during the tertiary treatment, an important amount of microplastics still discharged into the freshwaters through the WWTPs [40].

\subsection{Microplastics in the Terrestrial Ecosystem}

Studies in the occurrence of microplastics in the terrestrial ecosystem received little attention regarding the marine ecosystem. However, it is estimated that microplastic contamination on land might be 4-23fold larger than in the ocean [41]. Application of sewage sludge containing synthetic microbeads of microplastics on land constitutes a direct source of primary microplastics to the terrestrial environment. These synthetic microbeads are from personal care or household products to land [42-43]. The treatment works of sewage are enough to remove the majority of microplastics items from wastewater. However, 
many of these removed particles will be retained within the sludge [44-45]. Usually, the sludge resulted from sewage treatment is applied on arable land as fertilizers. This suggests that even at the deepest floor of soil, microplastic contamination can probably be founded. This is the case of European countries that apply between 4 and 5 million tones dry weight of pasteurized sewage sludge every year to their arable lands [70]. This practice let agricultural soil alone stored more microplastics than oceanic basins.

Sometimes, irrigation for agricultural soils is made directly by untreated wastewater derived from the effluent of washing machine and self-care products. These products are known with their microplastic contains. The direct application of this water should also contribute on the distribution of microplastic in the soil ecosystem. Assays were done with effluents derived from the washing machine after washing some specified clothes as new and aged jackets. Concentration of microplastics detected from this household wastewater was from 1000 to 627000 items $\mathrm{m}^{-3}$ [71-73]. Other sources of microplastics in soil are the larger plastic items accumulated illegally on some locality: after exposure to some environmental conditions, these large items are degraded to micro and nanoplastics. In addition, runoff from industrial and highly activated urban areas as well as some atmospheric transportations from these areas or others, contribute to the distribution of microplastics in the terrestrial environment $[72,73]$. The study done in an urban environment near Paris by Dris and his co-researchers had the aim to analyze the atmospheric fallout of microplastics in these areas. They showed a mean value of 29-280 items $\mathrm{m}^{-2} \mathrm{day}^{-1}$ [74].

However, the topsoil provides a potentially degradative environment for microplastics. Some terrestrial organisms may transfer these items to the deeper topsoil. A laboratory study showed the movement of microplastic beads by microarthropods (collembola) in soil environment. In addition, a vertical movement of PE microbead carried by earthworms was observed in a study published in 2017 by Rilling and his co-researchers. Land activities like tillage in agricultural soils could contribute in the spreading of microplastic particles along the terrestrial ecosystem [75].

\section{Microplastics Biodegradation}

As the manufacturing and using of plastics increase, the accumulation of microplastics on the environment increases. This is due to the non-perishable property of these polymers. It should be noted that, this property differs from one type of these polymers to another one. The focus on the microplastics is since most organisms up to humans can ingest them without feeling their presence in foods, drinks, or on the surface of the animals and zooplankton feeds.

Degradation of a polymer is all types of change in their physicochemical properties that can come after exposition into biotic or/and abiotic factors. In the case of abiotic factors, the process is known as deterioration [76]. Otherwise, in the actual review, we are focused on the biodegradation. Abiotic factors are defined as environmental factors such as humidity, temperature and, ultra-violet radiation (sunlight). On the other side, enzymes from organisms (higher or microorganisms) are the main biotic form that affects the polymers. Even though the biodegradation of microplastics is a complex process, the biodegradation of some of the most used type of plastics are described in many studies regarding the specific environment and specific microorganisms. Studies running until now found that only microorganisms (bacteria and fungi) are able to degrade the microplastics. Some microorganisms have the ability to start the process of biodegradation, others are able to complete the process and some others have the competence for a complete reaction (biodegradation). These microorganisms should be able to use the carbon backbone of the polymer as a carbon source. To achieve the process, some environmental conditions and other properties should be favorable. It is reported that the degradation on the seafloor is limited regarding to that on the surface of the water. This is because of the reduced sunlight penetration to the seafloor [77]. Here, the role of abiotic factors is clear that even it does not consist of complete deterioration of the microplastics, but it is helpful for complete and rapid biodegradation 


\subsection{Concept of Biodegradation}

The biodegradation is one of the two solutions to minimize the impact of the usage of polymers on the environment [78]. Dommergues and Mangenot (1972) define the biodegradation as decomposition by the action of microorganisms on substances: recycling of carbon, mineralization of organic compounds and generation of new biomass constitute the major results of this decomposition [78]. Here, the roles of microorganism still the more important. As shown by Lucas et al. (2008) the biodegradation consists of three stages: biodeterioration, biofragmentation and assimilation consecutively. However, the assimilation step is neglected in some biodegradation studies since for proving this reaction, expensive tools and methods should be used [78].

\subsection{Microorganisms Involved in Microplastics Biodegradation}

Microorganisms are distributed everywhere even in the extreme ecosystems. Extreme ecosystems are where the environmental conditions are extremes: high/low temperatures, high/low density, very basic/ acidic salinity, etc. They include the deepest seafloor, the caves, the highest mountains of the world and the inside of volcanic mountains. Additionally, microorganisms have a fast reproducing activity. In general, a bacterium can be developed during 24hours, under good environmental conditions. Bacteria able to live under extreme conditions like caves or in the deep of the seafloors should have the ability to secrete some specific enzymes or secondary metabolites. Some of them are autotrophic bacteria: able to produce their own primary material. In this fact, scientists should take advantage from these small organisms to solve more than one problem of environmental pollution.

Microorganisms involved at the beginning of plastic biodegradation are only those who are able to produce extracellular enzymes that can cleave the different bonds founding in the polymer. By this fact, biofilm formation which is responsible for the fixation of microorganism on the surface of the plastic is more important. Note that for each microplastic, specific microorganisms are involved. Sometimes more than two microorganisms can act together for a good result of biodegradation in a symbiotic relationship. In 1984, Shimao et al., discovered the symbiont relation between two Pseudomonas species who act together in the biodegradation of poly(vinyl alcohol) [115]. They found that the Pseudomonas putida VM15A can secrete an essential growth factor (Pyrroloquinoline Quinone) for the growing of the Pseudomonas sp VM15C on a poly(vinyl alcohol) suspended media [115]. They showed that the degrading bacteria could not be developed in the presence of poly(vinyl alcohol) without the presence of the second Pseudomonas putida. [115]. Oberbeckmann et al., 2016 reported that microbes colonize the aquatic plastic debris once these latter enter the marine environment. These microbes can be pathogenic, toxic, invasive or plastic degrading species [69]. Researches have been made with different microorganisms on different microplastics. Some of them are cited in the table found below this part.

The study done in a mangrove ecosystem in Peninsular Malaysia shown a capacity of Bacillus cereus and Bacillus gottheilii to degrading microplastics of PE, PET and PS. In this same study, after applying B.gottheilii on PP for a period of 40 days, $3.6 \%$ of PP weight loss was observed [79]. Sivan et al., have isolated a biofilm-producing strain of Rhodococcus ruber. This strain was first defined as polyethylenedegrading bacteria with a rate of $0.86 \%$ per week. Experimentations shown a high viability of the biofilm even after 60 days. In addition, upon exposed to the polyethylene surface, this strain adheres on it immediately [80]. This case can be a demonstration for: the strong the biofilm is forming, the good the degradation is done. Bacteria isolated from soil have also effects on microplastics. Genera of Pseudomonas (Pseudomonas species are well known for their good inert biofilm formation), Comamonas and Bacillus have been isolated and identified as Polyurethane (PU) users. They use the PU as a sole carbon source for their multiplication [81,82,83-84]. Another species isolated from the soil is revealed the reduction of polyethylene molecular weight by $30 \%$. It consists of the thermophilic bacterium Brevibacillus borstelensis which use this plastic material as the sole carbon and energy source [85]. 
Some fungi strains are involved in this small size plastics degradation. Here, genera of Emericella, Trichoderma, Asperigillus and others were isolated from the surface of polyester foam and approved to using this plastic material as a sole carbon source [86].

\subsection{Mechanism of Microplastics Biodegradation}

Studies for isolated plastics degrading microorganisms still multiplied but few of them demonstrate the real plastic biodegradation mechanism. Many enzymes involve from the beginning to the end of the process are secreted from a single microorganism or different ones. To understand these mechanisms, every chemical structure of the plastic should be studied. Many plastics have linear or ramified carbon chains similar to those of alkanes. Some of them involve lipids or polysaccharides additives materials. Starting with this concept, enzymes for these macromolecules' hydrolysis should be included in the mechanism. Strain of Pseudomonas species had been studied for the role of its alkane hydroxylase in the biodegradation of the low molecular weight polyethylene. Here, Jeon and Kim demonstrate that the transcription of alkane monooxygenase encoding gene "alk $B$ " in this strain increases by 4 times upon its incubation with low molecular weight polyethylene in a mineral medium supplemented for 15 days [87]. Some Pseudomonas spp. secretes enzymes like serine hydrolases, esterases and lipases that can serve for biodegradation of plastic materials. It is the case of the biodegradation of PHA, depolymerases that are serine hydrolases are able to attack the branch of chains and the cyclic components of the polymers [86]. Proteases enzymes secreted by some Bacillus spp. are also responsible of biodegradation of microplastics [86]. Other microorganisms like Amycoloptosis species and some Proteobacteria groups have effects respectively on polylactic acid and polypro-lactone with unknown mechanisms of their degradation: the enzymes responsible of the degradation were still unknown [86]. Secretion of biosurfactants makes the PE films relatively more hydrophilic by reducing their surface tension, which facilitates colonization of the bacteria on the polyethylene surface [47]. This factor let to say that some microorganisms are not capable to degrade the microplastics but able to let it more degradable by other ones. A diagram of the microbial degradation of the microplastics is illustrated in the figure found below.

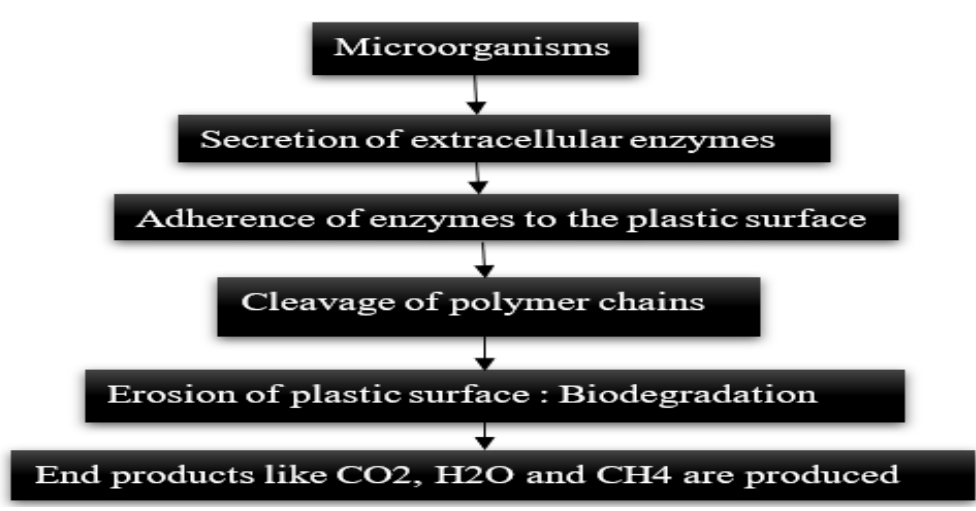

Figure: Diagram of microbial enzymatic biodegradation of plastic

\subsection{Limits of Microplastics Biodegradation}

Degradation of microplastics depends on different conditions including the environmental settings and the physico-chemical characteristics of the plastic material [109]. These physico-chemical properties can affect both the biotic and abiotic degradation since they can stop or reduce the attachment of the bacterial cell on the surface of the material (biofilm) [109]. Lambert et al., reported that the accessibility of enzymes is often limited in front of some plastics like PP, PE, PET due to their regular and short repeating units [110]. In the same way, some plastic materials have been described as exhibiting different sensitivities to the ultraviolet mediated degradation. As the most of time, biodegradation of 
microplastics depends on abiotic factors like the UV: less sensitivity of plastic material to UV should limit its biological degradation [111].

Availability of abiotic factors: physical and chemical conditions of the biodegradation environment constitute big effects on the acceleration of the microplastic biodegradation. Since these last ones have effects on the oxidation, cleavage, and morphological modifications of microplastic materials: plastics pretreated by one or more of these physical treatments, appear more susceptible to the phenomenon of biodegradation than the unpretreated ones. Examples have been demonstrated by Arkatkar and his friends in 2009 during their work in the biodegradation of polypropylene exposed to thermal pretreatment. They found that after 12 months, the biodegradation of this last one is enhanced than the biodegradation of the non-pretreated one [88].

In addition, the abundance of microbial communities can affect the microplastic biodegradation. It is reported that in benthic zones, the biodegradation of microplastics is not important due to the reducing density of microbial communities in these areas [114]. Contrary to these environments, in the less deep waters, where is the residency of diverse microbial communities of autotrophs, heterotrophs and symbionts, the biodegradation of microplastics is more active [114].

Table: Some microplastics degrading microorganisms isolated from different environments.

\begin{tabular}{|c|c|c|c|c|}
\hline $\begin{array}{c}\text { Type of } \\
\text { microplastics }\end{array}$ & Microorganisms & $\begin{array}{c}\text { Type of } \\
\text { microorganisms }\end{array}$ & Isolated from & Reference \\
\hline \multirow{4}{*}{ HDPE } & Achromobacter xylosoxidans & Bacteria & Soil & [46] \\
\hline & Streptomyces $s p$ & Bacteria & Soil & [47] \\
\hline & Pseudomonas, Bacillus & Bacteria & Coastal regions & [48] \\
\hline & Aspergillus spp. & Fungi & Marine ecosystem & {$[50]$} \\
\hline $\begin{array}{l}\text { Thermal treated } \\
\text { HDPE }\end{array}$ & Klebsiella pneumoniae & Bacteria & Plastic waste dumpsite & [49] \\
\hline \multirow{2}{*}{$\begin{array}{l}\text { Gamma } \\
\text { irradiated LDPE }\end{array}$} & Paecilomyces lilacinus & Fungi & $\begin{array}{c}\text { Endemic plant (Humboldtia } \\
\text { brunonis) }\end{array}$ & \multirow{2}{*}[51]{} \\
\hline & Lasiodiplodia theobromae & Fungi & $\begin{array}{l}\text { Endemic plant (Psychotria } \\
\text { flavida) }\end{array}$ & \\
\hline \multirow{7}{*}{ LDPE } & $\begin{array}{c}\text { Brevibacillus, } \\
\text { Cellulosimicrobium, } \\
\text { Lysinibacillus, Bacillus, } \\
\text { pseudomonas }\end{array}$ & Bacteria & Dumpsite & {$[53]$} \\
\hline & Acinetobacter pitti, & Bacteria & Soil & {$[52]$} \\
\hline & Aspergillus & Fungi & Dumpsite & {$[53]$} \\
\hline & Paenibacillus sp. & Bacteria & Landfill & {$[54]$} \\
\hline & Lysinibacillus sp. & Bacteria & Plastic samples & \multirow{2}{*}[55]{} \\
\hline & Salinibacterium $s p$. & Bacteria & Surface water & \\
\hline & Kocuria palustris M16 & Bacteria & Pelagic water & {$[56]$} \\
\hline PE & Enterobacter sp. & Bacteria & & [57] \\
\hline
\end{tabular}


Rachid and Doğruöz-Güngör / Eskişehir Technical Univ. J. of Sci. and Tech. C-Life Sci. and Biotech. 9 (2) - 2020

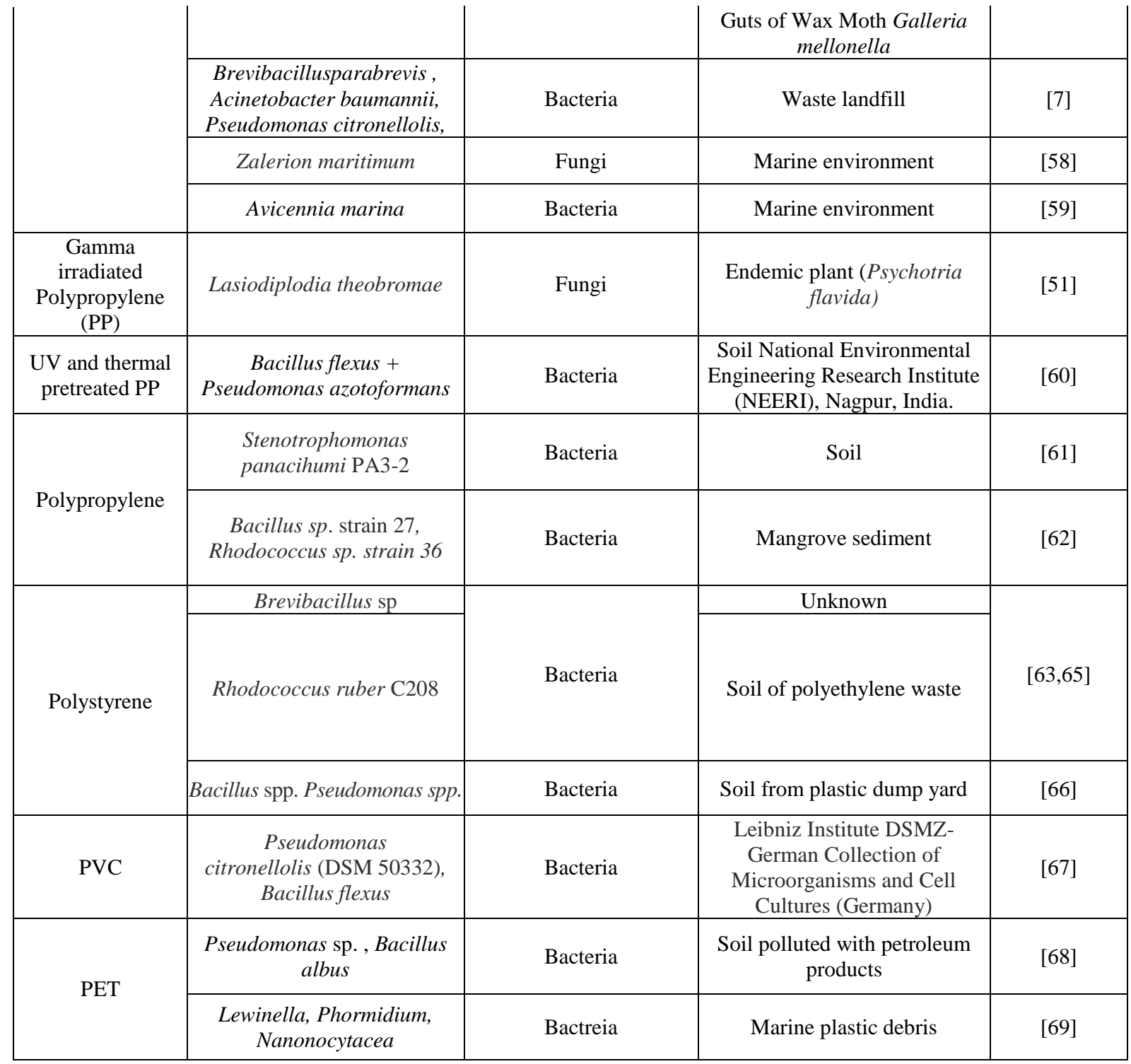

\section{TOXICITY AND EFFECTS OF MICROPLASTICS}

\subsection{Effects of Microplastics in Aquatic Environment}

Unfortunately, microplastics still increase in the marine environment. The increasing of the availability of these particles in this ecosystem has not only physical but also chemical effects towards the marine organisms. For understanding and clarifying the effects of these tiny particles towards organisms, experimentations have been done in laboratories with different organisms under different conditions.

Color, size, shape, density, charge, and the abundance of these light particles are some factors that increase their bioavailability in the aquatic environment [89]. For example, their small size makes them available to lower trophic organisms [90]. At the same time, some of the higher planktivorous could ingest microplastics during the normal feeding behavior or mistakenly as natural prey. It is the case of B.physalus that could be consuming microplastics during engulfing water [91]. In addition, the color and shape of the particles could look like some planktonic cells like diatoms which are the prey of some marine organisms. 
Physicochemical effects of the microplastics to the marine organisms can include fatal injuries like blockages through the digestive system, abrasions from objects, blockage of enzyme production, diminished feeding stimulus, nutrient dilution, reduced growth rates, lowered steroid hormone levels, delayed ovulation and reproductive failure, and absorption of toxins [100]. A significant reduction on the growth of microalgae was observed during their exposure to microplastics [101-102]. Furthermore, inhibitory effect of the microalgae would be enhanced by increasing the dose of microplastics exposure [99]. Exposition of Skeletonema costatum to PVC microplastics shows a very important decrease in chlorophyll production that explains the deficiency of the photosynthesis function inside these organisms [98]. The impacts on these microalgae constitute a big problem while these organisms are aquatic primary producers. This not only indicates the possibility of the microplastics distribution throughout the food network but also the disruption of this food web system.

Microplastics constitute the surface of other biological and/or chemical contaminants. Recently, pathogen microorganisms are founded on the surface of microplastics. Kirstein et al. have discovered important amount of pathogenic Vibrio parahaemolyticus on the surface of different microplastic particles like polypropylene, polyethylene and polystyrene collected from North and Baltic Sea [96]. In the same context, in 2017, a study carried out in the North Adriatic Sea was directed to characterize bacterial communities living on the microplastics founded in the sea surface [97]. Based on the 16S rDNA, more than 20 bacterial species were identified and the pathogenic fish bacteria Aeromonas salmonicida was identified for the first time on microplastics [97]. Furthermore, microplastics can be a vector of chemical contamination from land to the aquatic ecosystem. Pesticides, chemical fertilizers and other chemicals applied in soil could be attached on the surface of microplastics. Once migrated to the aquatic ecosystems through rains or other weathering conditions, these chemicals can affect the fauna as well as the flora of the polluted regions [114].

Furthermore, chemical additives on the plastic materials during their production could affect microplastic contaminated areas. Most of these additive materials are not bounded to the polymers. In addition, sometime the polymerization of plastic materials could not be completed. At these facts, residual monomers, solvents and additives can migrate away from the polymers as it is demonstrated in many works. Most of the used additive chemical material includes phthalates, brominated flame retardant and Bisphenol A (BPA) which are of endocrine disruptive potential [112-113]. Phthalates are used as plasticizers to provide more flexibility to the polymer matrix [113]. They are including in most plastic polymers like PVC, PET, polyvinyl acetates, and cellulosic [114]. These chemicals are generally considered to be stable over high temperature range and are easily dissolved in water. This explains their adsorption to organic and inorganic particles in both the water column and sediments.

\subsection{Effects of Microplastics in Continental Ecosystem}

In the continental ecosystem, microplastic accumulated in soil, freshwaters and rivers can affect the physico-chemical properties, plants, and organisms of these environments. As from the oceanic environment, the contamination of microplastic in continental ecosystem has the possibility to affect human through the food chain. Data about the effects of microplastic in the terrestrial environment are not yet provided but some studies revealed the effects of these particles in some soil animals and microbiota [103].

Earthworms, nematodes, mite, and isopods are some of soil invertebrates. Studies on earthworm species exposed to some microplastics show the toxicity on these organisms: mortality, obvious histopathological damages and immune system cases are observed in some of Eistenia species [103104]. In addition, it is observed that some earthworms ingest microplastics with a selective size way. Ingested micro-items are transported vertically or horizontally to other terrestrial surface: pollution of groundwater and migration through members of terrestrial food web are not escaped [105-106]. 
Soil organisms constitute an important part of the terrestrial ecosystem and nematodes appeared the most abundant animals distributed along with all the trophic levels in the soil food web. Nematodes are used as suitable indicators of soil quality [95]. However, researchers revealed the possibility of microplastics to be ingested by some nematodes like Caenorhabditis elegans. Authors observed a reduction in the intestinal calcium levels as well as an increased expression of the $g s t-4$ gene which is the oxidative stress gene on this organism exposed to microplastics [107]. These observations indicate intestinal and oxidative damages in this nematode. In other studies, physical and physiological effects are observed after exposure of these organisms to microplastics, like toxicity on locomotor behaviors, reduction of unc-17's and unc-47's expression which are the responsible genes of cholinergic and GABAergic neurons development [108].

Soil microbiota occupies a key position in the soil quality. Since most of soil microorganisms contribute to the protection and development of plants. Bacteria like Bradyrhizobium japonicum are able to fixe atmospheric nitrogen $\mathrm{N}_{2}$ to plants root after infected them and stimulate the nodules formations [94]. In addition, mycorrhizae are mutualisms between fungi and plants, in particular the roots. In this relation, the fungi transfer inorganic nutrients to the plants and on the other hand, the plant transfers carbohydrate to the fungi. Another soil microbiota has been observed to contribute to the soil bioremediation. It is the case of the fungus Zalerion maritimum which could utilize polyethylene by reducing their size and mass in a minimal growth medium [58]. However, assimilation or utilization of microplastics by some microorganisms can cause a shift of soil organic materials. Liu et al., demonstrate that the accumulation of microplastics on soil can stimulate the enzymatic activity, activate the increasing of the dissolved organic matters, and can decline the microbial community in soil [93].

As we are all dependent on each other, human also is affected by environmental microplastic pollution. A report done in 2017 by the nonprofit journalism organization (Orb Media) shows that $83 \%$ of 159 drinking water samples from five continents have been found contaminated with microplastics fibers. The risks are still unclarified, but as these tiny plastics are chemical as well as microorganism transporters, a long-term drinking of water containing microplastics can be toxic to humans [92].

\section{CONCLUSION}

The uses of plastics in general and the microplastics especially, are still increasing due to their using facilities and especially their low cost. In addition, the production of plastic materials is becoming a good factor for the increasing of the country's economy. However, microplastics are widespread through oceans, soil, freshwaters, and the atmosphere. Its main source remains the land-based activities since both primary and secondary microplastics pollutes come mostly from those activities. The impacts of these particles in the environment are with a danger in the fauna and flora of the whole world planet. The biodegradation of microplastics by different microorganisms have been approved and it can be facilitated by treatment of the debris by some abiotic factors like high temperature. However, the limit of using and manufacturing of plastic materials could be an effective solution for the diminution of microplastic debris accumulation.

\section{REFERENCES}

[1] Alshehrei F. Biodegradation of Synthetic and Natural Plastic by Microorganisms. Appl Environ Microb 2017; 5: 8-19.

[2] Shashoua Y. Conservation of Plastics: Materials Science, Degradation and Preservation. $1^{\text {st }}$ ed. Amsterdam, Boston: Elsevier/Butterworth-Heinemann, 2008.

[3] An analysis of European plastics production, demand and waste data. Plastics - the Facts, Plastics Europe, Brussels, 2019. 
[4] JPGL F, Nash R. Microplastics: Finding a consensus on the definition. Mar Pollut Bull 2019; 138: $145-147$

[5] Thompson RC, Olsen Y, Mitchell RP, Davis A, Rowland SJ, Jhon A.W.G, McGonigle D, Russell A.E. Lost at Sea: Where Is All the Plastic? Science 2004; 304: 777-908.

[6] GESAMP. Sources, fate and effects of microplastics in the marine environment: A global assessment (Kershaw, P.J., ed.). (IMO/ FAO/ UNESCO-IOC/ UNIDO/ WMO/ IAEA/ UN/ UNEP/ UNDP Joint Group of Experts on the Scientific Aspects of Marine Environmental Protection). Rep. Stud. GESAMP 2015. No. 90, 96p.

[7] Ramesh VK, Pramila R, Padmavanthy K, Mahalakshmi K. Brevibacillus parabrevis, Acinetobacter baumannii and Pseudomonas citronellolis - Potential candidates for biodegradation of low density polyethylene (LDPE). Bacteriol Res 2012; 4 :9-14.

[8] Lusher A. L, Tirelli V, O'Connor I. Microplastics in Arctic polar waters: the first reported values of particles in surface and sub-surface samples. Sci Rep-UK 2015; 5.

[9] Cole M, Webb H, Lindeque PK, Fileman ES, Halsband C, Galloway TS. Isolation of microplastics in biota-rich seawater samples and marine organisms. Sci Rep-UK 2014; 4.

[10] Wagner M, Scherer C, Alvarez- Muñoz D, Brennholt N, Bourrain X, Buchinger S, Fries E, Grosbois C, Klasmeier J, Marti T, Rodriguez-Mozaz S, Urbatzka R, Vethaak AD, WintherNielsen M, Reifferscheid G. Microplastics in freshwater ecosystems: what we know and what we need to know. Eviron Sci Eur 2016; 26: 12.

[11] Cole M, Lindeque P, Halsband C, Galloway TS. Microplastics as contaminants in the marine environment: a review. Mar Pollut Bull 2011; 62: 2588-2597.

[12] Costa MF, Ivar do Sul JA, Silva-Cavalcanti JS, Araújo M.C.B, Spengler A, Tourinho P. S.On the importance of size of plastic fragments and pellets on the strandline: a snapshot of a Brazilian beach. Environ Monit Assess 2010; 168: 299-304.

[13] Fendall LS, Swell MA. Contributing to marine pollution by washing your face: Microplastics in facial cleansers. Mar Pollut Bull 2009; 58: 1225-1228.

[14] Lesli H.A. Review of Microplastics in Cosmetics. Inst Env R 2014.

[15] Gouin T, Avalos J, Burnning I, Brzuska K, Graaf de J, Kaumanns J, Konong T, Meyberg M, Rettinger K, Schlatter H, Thomas J, Welie van R, Wilf T. Use of micro-plastic beads in cosmetic products in Europe and their estimated emissions to the North Sea environment. J SOFW 2015;144:1-33.

[16] Hernandez LM, Yousefi N, Tufenkji N. Are There Nanoplastics in Your Personal Care Products? EnvironN Sci Technol Lett 2017; 4:280-285.

[17] International Maritime Organization, IMO. Plastic particles in the ocean may be as harmful as plastic bags, report says. International Maritime Organization Press Briefing Archives, 2015.

[18] Andrady AL. Microplastics in the marine environment. Mar Pollut Bull 2011; 62: 1596-1605 
Rachid and Doğruöz-Güngör / Eskişehir Technical Univ. J. of Sci. and Tech. C-Life Sci. and Biotech. 9 (2) - 2020

[19] Lucas N, Bienaime C, Belloy C, Queneudec M, Silvestre F, Nava-Saucedo J. Polymer biodegradation: mechanisms and estimation techniques. Chemosphere 2008; 73:429-442.

[20] Mailhot B, Morlat S, Gardette JL. Photooxidation of blends of polystyrene and poly (vinyl methyl ether): FTIR and AFM studies. Polymer2000; 41: 1981-1988.

[21] Li WC, Tse HF, Fok L. Plastic waste in the marine environment: A review of sources, occurrence and effects. Sci Total Environ 2016; 566-567: 333-349.

[22] Barnes D.K.A, Galgani F, Thompson RC, Barlaz M. Accumulation and fragmentation of plastic debris in global environments. Philos T R Soc B 2009; 364:1985-1998.

[23] Zheng Y, Yanful EK, Bassi AS. A Review of Plastic Waste Biodegradation. Crit Rev Biotechnol $2005 ; 25: 243-250$.

[24] Gnanavel G, Mohana Jeya Valli VP, Thrirumarimurugan M, Kannadasan T. Degradation of polyethylene in the natural environment. INT J Res Eng Technol 2014; 2: 1-4.

[25] Alauddin A, Choudhoury IA, El Baradie MA, Hashmi M.S.J. Plastics and their machining: A review. J Mater Process Tech 1995; 54: 40-46.

[26] Scott G. Polymer in modern life. In: Scott G, editor. Polymers and the environment. Cambridge Royal Society of Chemistry, 2003. pp. 1-18.

[27] Eriksson C, Burton Harry, Fitch S, Schulz M, Van Den Hoff J. Daily accumulation rates of marine debris on sub-Antarctic island beaches. Mar Pollut Bull 2013; 66: 199-208.

[28] Alomar C, Estarellas F, Deudero S. Microplastics in theMediterranean Sea: deposition in coastal shallow sediments, spatial variation and preferential grain size. Mar Environ Res 2016; 111: 1-10.

[29] Andrady AL. Microplastics in the larine environment. Mar Environ Res 2011; 62: 1596-1605.

[30] Murphy F, Ewins C, Carbonnier F, Quinn B. Wastewater Treatment Works (WwTw) as a Source of Microplastics in the Aquatic Environment. Environ Sci Technol Lett 2016; 50: 5800-5808.

[31] Reed S, Clark M, Thompson R, Hughes KA. Microplastics in marine sediments near Rothera Research Station, Antarctica. Mar Pollut Bull 2018; 133: 460-463.

[32] Good TP, June JA, Etnier MA, Broadhurst G. Derelict fishing nets in Puget Sound and the Northwest Straits: Patterns and Threats to marine fauna. Mar Pollut Bull 2010; 60:39-50.

[33] Doyle MJ, Watson W, Bowlin NM. Sheavly S.B. Plastic particles in coastal pelagic ecosystems of the Northeast Pacific-ocean. Mar Environ Res 2011; 71: 41-52.

[34] Lobelle D, Cunliffe M. Early microbial biofilm formation on marine plastic debris. Mar Pollut Bull 2011; 62: 197-200.

[35] Lambert S, Wagner M. Microplastics Are Contaminants of Emerging Concern in Freshwater Environments: An Overview. In: Wagner M., Lambert S, editors. Freshwater Microplastics. The Handbook of Environmental Chemistry, Springer, Cham, 2018. pp: 1-23. 
[36] Klein S, Dimzon IK, Eubeler J, Knepper TP. Analysis, Occurrence, and Degradation of Microplastics in the Aqueous Environment. In: Wagner M, Lambert S, editors. Freshwater Microplastics. The Handbook of Environmental Chemistry, Springer, Cham, 2018. pp: 51 67.

[37] Xiong X, Wu C, Elser JJ, Mei Z, Hap Y. Occurrence and fate of microplastic debris in middle and lower reaches of the Yangtze River-From inland to the sea. Sci Total Environ 2019; 659: 6673.

[38] Peng G, Xu P, Zhu B, Bai M, Li D. Microplastics in freshwater river sediments in Shanghai, China: A case study of risk assessment in mega-cities. Environ Pollut 2018; 234: 448-456.

[39] Kamcikova G, Alic B, Bundschuh M, Gotvajn AZ. Wastewater treatment plant effluents as source of cosmetic polyethylene microbeads to freshwater. Chemosphere 2017; 188: 25-31.

[40] Li J, Liu H, Chen P. Microplastics in freshwater systems: A review on occurrence, environmental effects, and methods for microplastics detection. Water Res 2018; 137: 362-374.

[41] Horton AA, Walton A, Spurgeon DJ? Lahive E, Svendsen C. Microplastics in freshwater and terrestrial environments: Evaluating the current understanding to identify the knowledge gaps and future research priorities. Sci Total Environ 2017; 586: 127-141.

[42] Habib D, Locke DC, Cannone LJ. Synthetic fibers as indicators of municipal sewage sludge, sludge products, and sewage treatment plant effluents. Water Air Soil Poll 1998; 103: 1-8.

[43] Zubris K.A.V, Richards B.K. Synthetic fibers as an indicator of land application of sludge. Environ Pollut 2005; 138: 201-211.

[44] Magnusson K, Norén F. Screening of Microplastic Particles in and Downstream a Wastewater Treatment Plant. IVL Swedish Environmental Research Institute 2014.

[45] Mintening S, Int-Veen I, Löder M.G.J, Primpke S, Gredts G. Identification of microplastic in effluents of wastewater treatment plants using focal plane. Water Res 2016; 1-8.

[46] Kowalczyk A, Chyc M, Ryszka P, Latowski D. Achromobacter xylosoxidans as a new microorganism strain colonizing high-density polyethylene as a key step to its biodegradation. Environ Sci Pollut R 2016; 23:11349-11356.

[47] Farzi A, Dehnad A, Shirzad N, Norouzifard F. Biodegradation of high density polyethylene using Streptomyces species. J. Coast Life Med 2017; 11: 474-479.

[48] Devi RS, Ramya R, Kannan K, Antony AR, Kannan VR. Investigation of biodegradation potentials of high density polyethylene degrading marine bacteria isolated from the coastal regions of Tamil Nadu, India. Mar Pollut Bull 2019; 138: 549-560.

[49] Awasthi S, Srivastva P, Singh P, Tiwary D, Mishra PK. Biodegradation of thermally treated highdensity polyethylene (HDPE) by Klebsiella pneumoniae CH001. 3 Biotech 2017; 7:332.

[50] Devi RS, Kannan VR, Nivas D, Kannan K, Chandru S, Antony AR. Biodegradation of HDPE by Aspergillus spp. from marine ecosystem of Gulf of Mannar, India. Mar Pollut Bull 2015; 96: 1-2. 
[51] Sheik S, Chandrashekar KR, Swaroop K, Somashekarappa HM; Biodegradation of gamma irradiated low density polyethylene and polypropylene by endophytic fungi. Int Biodeter Biodegr 2015; 105: 21-29.

[52] Montazer Z, Habibi-Najafi MB, Mohebbi M, omromiehei A. Microbial Degradation of UVPretreated Low-Density Polyethylene Films by Novel Polyethylene-Degrading Bacteria Isolated from Plastic-Dump Soil. J Polym Environ 2018; 26: 3613-3625.

[53] Muhonja CN, Makonde H, Magoma G, Imbuga M. Biodegradability of polyethylene by bacteria and fungi from Dandora dumpsite Nairobi-Kenya. Plos One 2018; 13: 0198446.

[54] Bardají K. R, Furlan J.P.R, Stehling E, G. Isolation of a polyethylene degrading Paenibacillus sp. from a landfill in Brazil. Arch Microbiol 2019; 201: 699-704.

[55] Syranidou E, Karkanorachaki K, Amorotti F, Repouskou E, Kroll K, Kolvenbach B, Corvini P, Fabio Fava, Kalogerakis N. Development of tailored indigenous marine consortia for the degradation of naturally weathered polyethylene films. Plos One 2017; 12: 0183984.

[56] Harshvardhan K, Jha B. Biodegradation of low-density polyethylene by marine bacteria from pelagic waters, Arabian Sea, India. Mar Pollut Bull 2013; 77: 100-106.

[57] Ren L, Men L, Zhang Z, Guan F, Tian J, Wang B, Wang J, Zhang Y, Zhang W. Biodegradation of Polyethylene by Enterobacter sp. D1 from the Guts of Wax Moth Galleria mellonella. Int J Env Res Pun He 2019; 16: 1941.

[58] Paço A, Duarte K, Da Costa JP, Santos P.S.M, Pereira R, Pereira M.E, Freita AC, Duarte AC, Rocha-Santos T.A.P. Biodegradation of polyethylene microplastics by the marine fungus Zalerion maritimum. Sci Total Environ 2017; 586: 10-15.

[59] Shahnawaz M, Sangale MK, Ade AB. Rhizosphere of Avicennia marina (Forsk.) Vierh. as a landmark for polythene degrading bacteria. Environ Sci Pollut R 2016; 23: 14621-14635.

[60] Aravinthan A, Arkatkar A, Asha A. Juwarkar AA, Doble M. Synergistic growth of Bacillus and Pseudomonas and its degradation potential on pretreated polypropylene. Prep Biochem Biotech 2016; 46: 109-115.

[61] Jeon HJ, Kim NM. Isolation of mesophilic bacterium for biodegradation of polypropylene. Int Biodeter Biodegr 2016; 115: 244-249.

[62] Auta HS, Emenike CU, Jayanthi B, Fauziah SH. Growth kinetics and biodeterioration of polypropylene microplastics by Bacillus sp. And Rhodococcus sp. isolated from mangrove sediment; Mar Pollu Bull 2018; 127: 15-21.

[63] (Orr) IG, Hadar Y, Sivan A. Colonization, biofilm formation and biodegradation of polyethylene by a strain of Rhodococcus ruber. Appl Microbiol Biot 2004; 65: 97-104.

[64] Mor R, Sivan A. Biofilm formation and partial biodegradation of polystyrene by the actinomycete Rhodococcus ruber. Biodegradation 2008; 19: 851-858.

[65] Hwang JW, Choi YC, Park S, Lee EY. Biodegradation of gaseous styrene by Brevibacillus $s p$. using a novel agitating biotrickling filter. Biotechnol Lett 2008; 30: 1207-1212. 
Rachid and Doğruöz-Güngör / Eskişehir Technical Univ. J. of Sci. and Tech. C-Life Sci. and Biotech. 9 (2) - 2020

[66] Mohan AJ, Sekhar VC, Bhaskar T, Nampoothiri KM. Microbial assisted High Impact Polystyrene (HIPS) degradation. Bioresource Technol 2016; 213: 204-207.

[67] Giacomucci L, Raddadi N, Soccio M, Lotti N, Fava F. Polyvinyl chloride biodegradation by Pseudomonas citronellolis and Bacillus flexus. New Biotechnol 2019; 52: 36-41.

[68] León-Zayas R, Roberts C, Vague M, Mellies JL. Draft Genome Sequences of Five Environmental Bacterial Isolates That Degrade Polyethylene Terephthalate Plastic. Microbiol Resour Announc 2019; 5: e00237-19.

[69] Oberbeckmann S, Osborn A. M, Duhaime MB. Microbes on a Bottle: Substrate, Season and Geography Influence Community Composition of Microbes Colonizing Marine Plastic Debris Plos One 2016; 11: e0159289.

[70] Horton AA, Waton A, Spurgeon DJ, Lahvive E, Svendsen C. Microplastics in freshwater and terrestrial environments: Evaluating the current understanding to identify the knowledge gaps and future research priorities. Sci Total Environ 2017; 586: 127-141.

[71] Hartline NL, Bruce NJ, Karba SN, Ruff EO, Sonar SU, Holden PA. Microfiber masses recovered from conventional machine washing of new or aged garments. Environ Sci Technol Lett 2016; 50: $11532-11538$.

[72] He D, Luo Y, Lu S, Liu M, Song Y, Lei L. Microplastics in soils: Analytical methods, pollution characteristics and ecological risks. Trac-trend Anal Chem 2018; 109: 163-172.

[73] Blasing M, Amelung W. Plastics in soil: analytical methods and possible sources. Sci Total Environ 2018; 612: 422-435.

[74] Dris R, Gasperi J, Rocher V, Saad M, Renault N, Tassin B. Microplastic contamination in an urban area: a case study in Greater Paris. Environ Chem 2015; 12: 592-599.

[75] Maaß S, Daphi D, Lehmann A, Rilling MC. Transport of microplastics by two collembolan species. Envrion Pollut 2017; 225: 456-459.

[76] Restrepo-Flórez J, Bassi A, Thompson MR. Microbial degradation and deterioration of polyethylene - A review. Int Biodeter Biodegr 2014; 88: 83-90.

[77] Caruso G. Plastic Degrading Microorganisms as a Tool for Bioremediation of Plastic Contamination in Aquatic Environments J Pollut Eff Cont 2015; 3:3.

[78] Lucas N, Bienaime C, Belloy C, Queneudec M, Silvestre F, Nava- Saucedo J. Polymer biodegradation: Mechanisms and estimation techniques- A review. Chemosphere 2008; 73: 429442.

[79] Auta HS, Emenike CU, Fauziah SH. Screening of Bacillus strains isolated from mangrove ecosystems in Peninsular Malaysia for microplastic degradation. Eviron Pollut 2017; 231: 15521559.

[80] Sivan A, Szanto M, Pavlov V. Biofilm development of the polyethylene- degrading bacterium Rhodococcus ruber. Appl Microbiol Biot 2006; 72: 346-352. 
Rachid and Doğruöz-Güngör / Eskişehir Technical Univ. J. of Sci. and Tech. C-Life Sci. and Biotech. 9 (2) - 2020

[81] Ruiz C, Main T, Hilliard N, Howard GT. Purification and characterization of two polyurethanase enzymes from Pseudomonas chlororaphis. Int Biodeter Biodegr 1999; 43: 43-47.

[82] Russel JR. Biodegradation of polyester polyurethane by endophytic fungi. Appl Environ Microbiol 2011; 77: 6076-6084.

[83] Allen AB, Hilliard NP, Howard GT. Purification and characterization of a soluble polyurethane degrading enzyme from Comamonas acidovorans. Int Biodeter Biodegr 1999; 43: 37-41.

[84] Howard GT, Blake RC. Growth of Pseudomonas fluorescens on a polyester-based polyurethane and the purification and characterization of a polyurethanase-protease enzyme. Int Biodeter Biodegr 1998; 42:7-12.

[85] Hadad D, Geresh S, Sivan A. Biodegradation of polyethylene by the thermophilic bacterium Brevibacillus borstelensis. J Appl Microbiol 2005; 98: 1093-1100.

[86] Bhardwaj H, Gupta R, Tiwari A. Community of Microbial Enzymes Associated with Biodegradation of Plastics. J Polym Environ013; 21: 575-579.

[87] Jeon HJ, Kim MN. Functional analysis of alkane hydroxylase system derived from Pseudomonas aeruginosa $\mathrm{E} 7$ for low molecular weight polyethylene biodegradation I Int Biodeter Biodegr 2015; 103: 141-146.

[88] Arkatkar A, Arutchelvi J, Uppara PV, Doble M, Degradation of unpretreated and thermally pretreated polypropylene by soil consortia. Int Biodeter Biodegr 2009; 63:106-111.

[89] Wright SL, Thompson RC, Galloway TS. The physical impacts of microplastics on marine organisms: A review. Environ Pollut 2013; 178: 483-492.

[90] Moore J.C. Synthetic polymers in the marine environment: A rapidly increasing, long-term threat. Environ Res 2008; 108:131-139.

[91] Fossi MC, Panti C, Guerranti C, Coppola D, Giannetti M, Marsili L, Minutoli R. Are baleen whales exposed to the threat of microplastics? A case study of the Mediterranean fin whale (Balaenoptera physalus). Mar Pollut Bull 2012; 64: 2374-2379.

[92] Fox A, McGarity L, Bergen M. Global Scientific Study Finds Microscopic Plastic Fibers Contaminating Tap Water. Orb one world one story. Washington, USA, 2017. https://orbmedia.org/sites/default/files/Orb\%20Media\%20Microscopic\%20Plastics\%20Press\%2 0Release\%20SEP\%205\%202017.pdf

[93] Liu HF, Yang X.M, Liu G, Liang CT, Chen H, Ritsema CJ, Geissen VResponse of soil dissolved organic matter to microplastic addition in Chinese loess soil. Chemosphere 2017; 185: 907-917

[94] Madigan MT, Bender KS, Buckley DH, Sattley WM, Stahl DA. Microbial Symbioses with Microbes, Plants, and Animals. In: Madigan MT, Bender KS, Buckley DH, Sattley WM, Stahl DA, editors. Brock Biology of Microorganisms. Pearson, 2019. pp: 736.

[95] Yeates GW, Bongers T, De Goege R.G.M, Freckman DW, Georgieva SS. Feeding Habits in Soil Nematode Families and Genera--An Outline for Soil Ecologists. J Nematol 1993; 25: 315-331. 
Rachid and Doğruöz-Güngör / Eskişehir Technical Univ. J. of Sci. and Tech. C-Life Sci. and Biotech. 9 (2) - 2020

[96] Kirstein IV, Kirmizi S, Wichels A, Grain-Fernandez A, Erler R, Löder M, Gerdts G. Dangerous hitchhikers? Evidence for potentially pathogenic Vibrio spp. on microplastic particles. Mar Environ Res 2016; 120: 1-8.

[97] Viršek MK, Koren M.N L.Š. Microplastics as a vector for the transport of the bacterial fish pathogens species Aeromonas salmonicida. Mar Pollut Bull 2017; 125: 301-309

[98] Zhang C, Chen X, Wang J, Tan L. Toxic effects of microplastic on marine microalgae Skeletonema costatum: Interactions between microplastic and algae. Environ Pollut 2017; 220: 1282-1288.

[99] Mao Y, Ai H, Chen Y, Zhang Z, Zeng P, Kang L, Li W, Gu W, He Q, Li H. Phytoplankton response to polystyrene microplastics: Perspective from an entire growth period. Chemosphere 2018; 208: 50-68.

[100] Galgani F, Fleet D, Van Franeker J, Katsanevakis S, Maes T, Mouat J, Oosterbaan L, Poitou I, Hanke G, Thompson R, Amato E, Birkun A, Janssen C. MARINE STRATEGY FRAMEWORK DIRECTIVE Task Group 10 Report Marine litter. European Union, 2010.

[101] Lyakurwa DJ. Uptake and Effects of Microplastic Particles in Selected Marine Microalgae Species; Oxyrrhis marina and Rhodomonas baltica. MSc, Norwegian University of Science and Technology, Trondheim, Norweg, 2017.

[102] Bergami E, Pugnalini S, Vannucini ML, Manfra L, Faleri C, Savorelli F, Dawson KA, Corsi I. Long-term toxicity of surface-charged polystyrene nanoplastics to marineplanktonic species Dunaliella tertiolecta and Artemia franciscana. Aquat Toxicol 2017; 189:159-169.

[103] He D, Luo Y, Lu S, Liu M, Song Y, Lei L. Microplastics in soils: Analytical methods, pollution characteristics and ecological risks. Trac-trend Anal Chem 2018; 109: 163-172.

[104] Rodriguez- Seijo A, Lourenço J, Rocha-Santos T.A.P, Da Costa J, Duarte AC, Vala H, Preira R. Histopathological and molecular effects of microplastics in Eisenia Andrei Bouché. Environ Pollut 2017; 220: 495-503.

[105] Lwanga EH, Vega JM, Quej VK, Chi J.L.A, Van der Plog L, Besseling E, Koelmans AA, Geissen V. Field evidence for transfer of plastic debris along a terrestrial food chain. Sci Rep-UK 2017; 7.

[106] Lwanga EH, Gertsen H, Gooren H, Peters P, Salani T, Van der Ploeg M, Besseling E, Koelmans AA, Geissen V. Microplastics in the terrestrial ecosystem: implications for Lumbricus terrestris (Oligochaeta, Lumbricidae). Sci Total Environ 2016; 50: 2685-2691.

[107] Lei L, Wu S, Liu M, Song Y, Fu Z, Shi H, Raley-Susman KM, He D. Microplastic particles cause intestinal damage and other adverse effects in zebrafish Danio rerio and nematode Caenorhabditis elegans. Sci Total Environ 2018; 619-620: 1-8.

[108] Lei L, Liu M, Song Y, Shibo L, Hu J, Cao C, Xie B, Shi H, He D. Polystyrene (nano)microplastics cause size dependent neurotoxicity, oxidative damages and other adverse effects in Caenorhabditis elegans. Environ Sci-nano 2018; 5: 2009-2020.

[109] Lambert S, Sinclair C, Boxall A. Occurrence, Degradation, and Effect of Polymer-Based Materials in the Environment. In: Whitacre D. editors. Reviews of Environmental Contamination and Toxicology. Springer, Charm, 2014; 227. pp 1-53. 
[110] Artham T, Doble M. Biodegradation of aliphatic and aromatic polycarbonates. Macromol Biosci 2007; 8: 14-24.

[111] Falcão G.A.M, Almeida TG, Bardi M.A.G, Carvalho LH, Canedo E. L. PBAT/organoclay composite flms - part 2: effect of UV aging on permeability, mechanical properties and biodegradation. Polym Bull 2019; 76: 291-301.

[112] Sánchez-Avila J, Bonet J, Velasco G, Lacorte S. Determination and occurrence of phthalates, alkylphenols, bisphenol A, PBDEs, PCBs and PAHs in an industrial sewage grid discharging to a Municipal Wastewater Treatment Plant. Sci Total Environ 2009; 407: 4157-4167.

[113] Bergé A, Cladière M, Gasperi J, Coursimault A, Tassin B, Moilleron R. Meta-analysis of environmental contamination by phthalates. Environ Sci Pollut R 2013; 20: 8057-8076.

[114] Hermabessiere L, Dehaut A, Paul-Pont I, Lacroix C, Jezequel R, Soudant P, Duflos G. Occurrence and effects of plastic additives on marine environments and organisms: A review. Chemosphere 2017; 182: 781-793.

[115] Shimo M, Yamamoto H, Ninomiya K, Kato N, Adachi O, Aeyama M, Sakazawa C. Pyrroloquinone Quinone as an Essential Growth Factor for a poly(vinyl alcohol)-degrading Symbiont, Pseudomonas sp VM15C. Agr Biol Chem Tokyo 19884; 48: 2873-2876. 